\title{
PHYLOGENETIC ANALYSIS OF LSU AND SSU RDNA GROUP I INTRONS OF LICHEN PHOTOBIONTS ASSOCIATED WITH THE GENERA XANTHORIA AND XANTHOMENDOZA (TELOSCHISTACEAE, LICHENIZED ASCOMYCETES) ${ }^{1}$
}

\author{
Shyam Nyati ${ }^{2}$ \\ Institute of Plant Biology, University of Zurich, Zollikerstrasse 107, Zurich 8008, Switzerland \\ Department of Radiation Oncology, University of Michigan, 109 Zina Pitcher Place, Ann Arbor, Michigan 48109, USA
}

Debashish Bhattacharya

Department of Ecology, Evolution and Natural Resources, Institute of Marine and Coastal Science, Rutgers University, 59 Dudley Road, New Brunswick, New Jersey 08901, USA

Silke Werth

Faculty of Life- and Environmental Sciences, University of Iceland, Sturlugata 7, Reykjavík 101, Iceland

and Rosmarie Honegger

Institute of Plant Biology, University of Zurich, Zollikerstrasse 107, Zurich 8008, Switzerland

We studied group I introns in sterile cultures of selected groups of lichen photobionts, focusing on Trebouxia species associated with Xanthoria s. lat. (including Xanthomendoza spp.; lichen-forming ascomycetes). Group I introns were found inserted after position 798 (Escherichia coli numbering) in the large subunit (LSU) rRNA in representatives of the green algal genera Trebouxia and Asterochloris. The 798 intron was found in about $25 \%$ of Xanthoria photobionts including several reference strains obtained from algal culture collections. An alignment of LSU-encoded rDNA intron sequences revealed high similarity of these sequences allowing their phylogenetic analysis. The 798 group I intron phylogeny was largely congruent with a phylogeny of the internal transcribed spacer region, indicating that the insertion of the intron most likely occurred in the common ancestor of the genera Trebouxia and Asterochloris. The intron was vertically inherited in some taxa, but lost in others. The high-sequence similarity of this intron to one found in Chlorella angustoellipsoidea suggests that the 798 intron was either present in the common ancestor of Trebouxiophyceae, or that its present distribution results from more recent horizontal transfers, followed by vertical inheritance and loss. Analysis of another group I intron shared by these photobionts at small subunit position 1512 supports the hypothesis of repeated lateral transfers of this intron among some taxa, but loss among others. Our data confirm that the history of group I introns is characterized by repeated horizontal transfers,

\footnotetext{
${ }^{1}$ Received 24 June 2013. Accepted 7 September 2013.

${ }^{2}$ Author for correspondence: e-mail: shyamnya@med.umich.edu. Editorial Responsibility: O. De Clerck (Associate Editor)
}

and suggests that some of these introns have ancient origins within Chlorophyta.

Key index words: Lichen; LSU 798 group I intron; Photobiont; rbcL; SSU 1512 group I intron; Trebouxia; Trebouxiophyceae

List of Abbreviations: ITS, internal transcribed spacer; LSU, large subunit; SSU, small subunit

Group I introns are a distinctive group of RNA sequences that catalyze their own excision from precursor RNA transcripts with concomitant exon ligation. Group I introns have a random and highly biased distribution owing to the two intron transfer mechanisms of reverse splicing and homing (Hoshina and Imamura 2009). Group I introns have been reported in various genes from a variety of organisms (Michel and Westhof 1990). About 2,939 group I introns (for details, see http://www.rna.icmb.utexas.edu/SAE/ 2C/Distributions/g12tpt.php) have been identified in eukaryotic genomes (Haugen et al. 2005a, Nielsen and Johansen 2009, Bachar et al. 2013). Of these, 2,311 are found in the nucleus at dozens of sites in small and large subunit (SSU, LSU) ribosomal DNA. About 235 occur in mitochondrial genes and 393 in plastid DNA. Group I introns are characterized by four conserved core sequences $(\mathrm{P}, \mathrm{Q}, \mathrm{R}$, and $\mathrm{S})$ and ten conserved secondary structures (P1-P10; Burke et al. 1987). Five major subgroups of group I introns, termed IA, IB, IC, ID, and IE, are recognized based on secondary structure (Michel and Westhof 1990) and are always inserted into highly conserved regions of rRNA genes (Johansen et al. 1996). All group I introns catalyze their excision from primary transcripts using guanosine as a cofactor. Many of these ribozymes are 
autocatalytic, others rely on host-derived factors to facilitate splicing (Cech 1988, Cech et al. 1994). Among two Chlorella photobiont species of the ciliate Paramecium bursaria, a monophyletic clade of six introns was found, all of them derived from an ancestral intron (Csw.L2449) that had spread into heterologous sites (Hoshina and Imamura 2009). Some of these introns share common internal guide sequences, but in others these sequence fragments are inserted further upstream (Hoshina and Imamura 2009). These Chlorella photobionts are proposed to be a model system for studies on how group I introns insert at novel sites.

In eukaryotic microorganisms, horizontal transfer of group I introns appears to be the rule, rather than the exception. Therefore, the mapping and phylogenetic characterization of the widespread, but scattered nuclear group I introns can potentially clarify pathways and mechanisms of intron movement among eukaryotes (Einvik et al. 1998). Various studies have focused on the mechanisms underlying group I intron mobility. Many group I introns in the genomes of plastids, mitochondria, phages, and eubacteria contain open reading frames (ORFs) that encode endonucleases. These endonucleases mediate sequence-specific "homing" of group I introns into allelic sites (Dujon 1989). Although group I introns do not normally contain more than one ORF, the intron in the $\operatorname{cox} 1$ gene of the nonphotosynthetic, parasitic chlorophyte Helicosporidium sp. contains two ORFs (Pombert and Keeling 2010). Intron movement can also occur via reverse splicing, as demonstrated for the Tetrahymena thermophila LSU group I intron (Sogin et al. 1986).

Intron loss appears to be common as demonstrated by the "optional" distribution of group I introns within closely related taxa (Bhattacharya et al. 1996a,b). At the RNA level, intron loss seems to occur by reverse transcription of an intron-less RNA followed by homologous recombination with the intron containing genomic copy of the coding region (Dujon 1989). In some eukaryotic lineages (e.g., plants, including green algae, charophytes, red algae, or ciliates, fungi, etc.) mobility conferring ORFs have not yet been found in group I introns. This suggests that intron mobility (and loss) is likely to be mediated by reverse splicing that does not rely on a group I intron-encoded ORF (Bhattacharya et al. 1996b). However, in myxomycetes (Amoebozoa) such as Didymium iridis and Physarum polycephalum, nuclear group I introns spread extensively via homing (e.g., Ruoff et al. 1992, Haugen et al. $2005 \mathrm{~b})$. Intron sequences encoding homing endonucleases have also been reported from lichenized ascomycetes (Reeb et al. 2007). Putative group I introns were found in nuclear of the rSSU gene of the nonlichenized ascomycetes Phialophora americana, P. europaea (both saprotrophs), and P. verrucosa (human pathogen; Dothideomycetes), which were found to be monophyletic along with introns of lichen-forming ascomycetes Porpidia crustulata
(Lecanoromycetes) and Arthonia lapidicola (Arthoniomycetes; Harris and Rogers 2011). During a large phylogenetic survey of green algae, 23 distantly related isolates were found to contain at least one group I intron in the chloroplast $r b c \mathrm{~L}$ gene, all of them with distinct evolutionary origins. These introns were inserted either after position 462 or 699 (McManus et al. 2012).

The lichen symbiosis is particularly interesting with regard to group I intron presence and distribution. In lichen-forming ascomycetes, several group I introns at 13 different insertion positions within the nuclear SSU rDNA have been identified (Bhattacharya et al. 2002). The SSU rDNA intron variation observed by DePriest (1993) in a population of Cladonia chlorophaea was due to optional group I introns, which varied in number, position, restriction pattern, and size. Some of these insertion positions are unique, whereas others (516, 943, 1,046, and 1,506) are also found in other organisms including unicellular green algae (Gargas et al. 1995b). Within the monophyletic Parmeliaceae (Lecanorales; more than 60 species investigated) correlations between intron insertion sites, and ecological and geographic parameters were observed (Gutierrez et al. 2007). Because the green algal photobionts of lichen-forming fungi contain numerous nuclear-encoded rDNA group I introns, they are a model group to study the origin and phylogeny of these sequences (Bhattacharya et al. 1994, 1996a,b, 1998). Friedl et al. (2000) concluded that the SSU rDNA 1,512 group I intron was present in the common ancestor of the green algal classes Trebouxiophyceae, Chlorophyceae, and Ulvophyceae, and that it was laterally transferred at least three times among species of Trebouxia de Puymaly. They also concluded that intron loss was a common event during chlorophyte evolution. The green algal SSU group I introns at insertion sites 1,056, 1,506, and 1,512 (position relative to the Escherichia coli coding region) form distinct phylogenetic lineages based on the insertion site (Bhattacharya et al. 1994, 1996b). The intron phylogenies were largely congruent with the rDNA (i.e., host cell) phylogeny, suggesting vertical inheritance of the introns rather than lateral transfers during the evolution of green algae, with some exceptions being described by Friedl et al. (2000) and Bhattacharya et al. (2001).

Del Campo et al. (2010a,b) partially sequenced plastid LSU rDNA in 15 Trebouxia and Asterochloris species and observed a high diversity of group I introns. The resulting phylograms revealed two main clades, one comprising A. erici, A. glomerata, and $A$. irregularis, the other $T$. arboricola, $T$. crenulata, T. decolorans, T. shomanii, and T.jamesii. The authors suggested combining the phylogenetic analyses of the chloroplast and nuclear (nrITS) for improving phylogenetic accuracy (Del Campo et al. 2010a,b), described different group I introns (at position cL2449 and cL2504) in chloroplast LSU 
rDNA in Trebouxia photobiont within the same thallus of Ramalina farinacea (L) Ach., and speculated on presence of different photobiont species within a thallus.

In studies of the genetic diversity among green algal photobionts of Xanthoria s. lat. and Xanthomedo$z a$ spp. (lichen-forming ascomycetes), several Trebouxia strains and species were found to contain group I introns (Nyati et al. 2014). Moreover, these lichenized fungi associate with a well-defined, limited number of algal strains. Hence, this group of lichen photobionts represents a model system to study intron gains and losses in Trebouxia. The genus Asterochloris Tschermak-Woess forms lichen symbioses with Cladonia and other lichenized ascomycetes. We included type strains of Asterochloris to infer whether some introns could be ancient, as evidenced by intron sharing among Trebouxia and Asterochloris lineages. The main aim of this study was to characterize the group I introns and investigate the possibility of intron gains and losses among photobionts associated with lichen-forming ascomycetes of the genera Xanthoria s. lat. and Xanthomendoza. For this purpose, we: (i) characterize a newly found nuclear LSU rDNA group I intron at site 798 (L798); (ii) determine the distribution of the L798 and nuclear SSU rDNA 1512 (S1512) group I introns; and (iii) investigate congruence between nrITS and intron phylogenies among green algal lichen photobionts of the genera Trebouxia and Asterochloris.

\section{MATERIALS AND METHODS}

Lichen collection, storage, and photobiont isolation and culture. Photobionts were isolated and cultured as described (Honegger 2003) from several Xanthoria spp. including the broadly sampled $X$. parietina (Table 1 ). Type cultures of algal strains were obtained from the Culture Collection of Algae at the University of Innsbruck, Austria (IB/ASIB; Table 2). All cultured algal strains included in this study including reference strains of sterile algal cultures are stored in liquid nitrogen at the Institute of Plant Biology, University of Zürich, Switzerland, following the method of Honegger (2003).

DNA extraction, PCR amplification, and sequencing. Genomic DNA from algal isolates or whole lichens was extracted using the GFX PCR, DNA, and Gel Band Purification Kit (Amersham Biosciences, Little Chalfont, UK) according to the manufacturer's protocol. PCR amplification of a partial LSU rDNA fragment (position 660-1,100 of T. asymmetrica, Z95380) was done with newly designed primers (Table 3). The PCR reactions were performed in $50 \mu \mathrm{L}$ reaction volumes containing a reaction mix of $0.2 \mathrm{mM}$ of each of four dNTPs, $1.5 \mu \mathrm{M}$ of each PCR primer, and 1.25 U of Taq DNA polymerase (Sigma Aldrich, Buchs, SG, Switzerland), and $5 \mu \mathrm{L}$ of $10 \times$ PCR buffer (100 mM Tris-HCl, pH 8.3, $500 \mathrm{mM}$ $\mathrm{KCl}, 15 \mathrm{mM} \mathrm{MgCl}_{2}$, and $0.01 \%$ gelatin). Reactions were performed in a PTC 200 DNA engine (MJ Research Inc., Watertown, MA, USA) with the following conditions: initial denaturation for $3 \mathrm{~min}$ at $95^{\circ} \mathrm{C}$, followed by 30 cycles of $30 \mathrm{~s}$ at $95^{\circ} \mathrm{C}, 30 \mathrm{~s}$ at $60^{\circ} \mathrm{C}$, and $1 \mathrm{~min}$ at $72^{\circ} \mathrm{C}$, and a final extension for $10 \mathrm{~min}$ at $72^{\circ} \mathrm{C}$. Newly designed intron-specific primers were used for PCRs (Table 3), which were carried out with genomic DNA isolated from algal strains and from whole-lichen DNA extracts. PCR amplification was carried out with the following settings: $3 \mathrm{~min}$ at $95^{\circ} \mathrm{C}, 30$ cycles of $30 \mathrm{~s}$ at $95^{\circ} \mathrm{C}, 40 \mathrm{~s}$ at $56^{\circ} \mathrm{C}$, and $1 \mathrm{~min} 20 \mathrm{~s}$ at $72^{\circ} \mathrm{C}$ with final extension at $72^{\circ} \mathrm{C}$ for $10 \mathrm{~min}$. Sequencing was carried out using ABI Prism BigDye Terminator Mix V3.0 Cycle Sequencing Kit (Life Technologies, Rotkreuz, Switzerland) following the protocol of the manufacturer, and capillary electrophoresis of cycle sequencing products was performed on an Applied BioSystems ABI 3730 DNA Analyzer (Life Technologies).

Sequence alignment, secondary structure prediction, and phylogenetic analysis. Sequence contigs were assembled using Sequencher $^{\mathrm{TM}}$ 4.2.2 (Gene Codes Corp., Ann Arbor, MI, USA) and ambiguous positions were manually corrected. The final sequences were aligned using ClustalX (Thompson et al. 1997). The resulting alignment was visually checked for any discrepancies and manually corrected on MacClade V5.0 (Maddison and Maddison 2002). Intron insertion position was determined based on BLAST searches and sequence alignments. The putative secondary structure of the L798 intron was determined using comparisons to existing structures and m-fold (Zuker 2003) following the guidelines of Cech (1988) and Cech et al. (1994).

Maximum likelihood (ML) analysis was carried out using phylogenetic analysis using parsimony (PAUP) 4.0 b10 (Swofford 2003). Bayesian phylogenetic reconstruction was performed with MrBayes version 3.1.2 (Huelsenbeck and Ronquist 2001, Ronquist and Huelsenbeck 2003). To determine the best models according to the Akaike Information Criterion (AIC) criterion (Sakamoto et al. 1986, Posada and Buckley 2004) for ML and Bayesian phylogenetic analyses, MrModeltest version 2.3 (Nylander 2004) was applied to each data set. For the LSU and SSU green algal and SSU intron data sets, the general time reversible (Tavaré 1986) $(\mathrm{GTR}+\mathrm{G})$ model provided the best fit to the data as determined by AIC in MrModeltest. In contrast, the model best describing the LSU intron data set according to AIC was a version of the $\mathrm{GTR}+\mathrm{I}+\mathrm{G}(\mathrm{AIC}=8,411.15)$, although its AIC was only slightly lower than that of GTR $+\mathrm{G}$ model $(\mathrm{AIC}=8,411.28)$. Using the models determined by AIC in MrModeltest, ML and Bayesian analyses were performed on three data sets: (i) Twenty-eight rDNA sequences of the rDNA region excluding all introns, i.e., the "host" of the intron (data set "LSU host"), compiled for comparability with the LSU L798 intron sequences. The host cell phylogeny, as presented in Figure 1, is based on alignments of the complete ITS region, including the 5.8S rRNA gene. (ii) The LSU intron, comprising 31 sequences ("LSU intron"); and (iii) 36 DNA sequences of the SSU S1512 intron ("SSU intron"). To assess for statistical support, the ML analysis in PAUP used 100 bootstrap replicates in a heuristic search based on optimality criterion likelihood, with random addition of sequences. Maximum parsimony analysis was performed in PAUP with 100 bootstraps. Tree bisection-reconnection was used as a branch-swapping algorithm. In MrBayes, analyses were run for five Mio generations with four chains sampling the parameter space, sampling trees every 1,000 generations for a total of 5,000 trees, reaching stationarity, and receiving effective sample sizes $>3,000$ as assessed using Tracer version 1.5 (Rambaut and Drummond 2007). Of the sampled trees, $10 \%$ were discarded as burn-in. TreeAnnotator version 1.6.0, part of the Beast software (Drummond et al. 2012), was used to summarize trees and create a maximum clade credibility tree which was visualized using FigTree version 1.4.1 (Rambaut 2008).

To compare whether partitioned rDNA host and intron data sets were homogeneous, incongruence length difference tests (Farris et al. 1995) were performed on two combined data sets in PAUP, using 1,000 replicates and a heuristic search strategy, with parsimony as optimality criterion. The first combined data set contained 23 sequences of the L798 intron with corresponding rDNA host sequences ("combined 
TABLE 1. List of samples analyzed in this study for LSU and SSU introns.

\begin{tabular}{|c|c|c|c|c|c|}
\hline 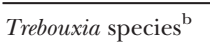 & Isolated from Xanthoria sp. & Country & Voucher $\mathrm{No}^{\mathrm{a}}$ & ITS accession no. & LSU accession no. \\
\hline $\begin{array}{l}\text { T. arboricola } \\
\text { de Puymaly }\end{array}$ & X. calcicola Oxner & $\mathrm{CH}$ & P-105-I-a & AJ969542 & AM261263 \\
\hline T. arboricola & $X$. calcicola & $\mathrm{CH}$ & P-141-II & AJ969552 & \\
\hline T. arboricola & $\begin{array}{l}\text { X. capensis Kärnefelt, } \\
\text { Arup \& L. Lindblom }\end{array}$ & $\mathrm{ZA}$ & P-306-I-a & AJ969591 & AM261277 \\
\hline T. arboricola & X. ectaneoides (Nyl.) Zahlbr. & $\mathrm{F}$ & P-158-IV-mc & AJ969560 & \\
\hline T. arboricola & $X$. ectaneoides & I & L-43 & AJ969523 & \\
\hline T. arboricola & X. ectaneoides & $\mathrm{TN}$ & P-174-II-aA & AJ969565 & \\
\hline T. arboricola & X. ligulata (Körb.) P. James & $\mathrm{NZ}$ & P-17-I-a ${ }^{c}$ & A]969518 & AM261260 \\
\hline T. arboricola & $X$. ligulata & NZ & P-17-II-a & A]969519 & \\
\hline T. arboricola & $X$. ligulata & $\mathrm{NZ}$ & P-53-I-a & AJ969528 & \\
\hline T. arboricola & $X$. ligulata & NZ & P-54-II-a & A]969530 & \\
\hline T. arboricola & X. parietina (L.) Beltr. & GB & P-18-I-a & AJ969520 & \\
\hline T. arboricola & $X$. parietina & $\mathrm{CY}$ & P-5-I-a-A & AJ969510 & \\
\hline T. arboricola & X. parietina & IS & P-198-II-a & AJ969568 & \\
\hline T. arboricola & X. parietina & IS & P-210-I-a & A]969570 & \\
\hline T. arboricola & $X$. parietina & $\mathrm{F}$ & P-7-I-a & AJ969512 & \\
\hline T. arboricola & $X$. parietina & $\mathrm{CH}$ & P-320-III-a & AJ969604 & AM261279 \\
\hline T. arboricola & $\begin{array}{l}\text { X. polycarpa }(\text { Hoffm. }) \\
\text { Th.Fr. ex Rieber }\end{array}$ & $\mathrm{NZ}$ & P-48-III-a & AJ969526 & \\
\hline T. arboricola & $X$. sp. & CY & P-5-I-a & AJ969510 & \\
\hline T. arboricola & $X$. sp. & AUS & $\mathrm{P}-276-\mathrm{I}-\mathrm{a}^{\mathrm{c}}$ & A]969581 & AM261275 \\
\hline T. arboricola & $\begin{array}{l}X . \text { hirsuta Eichenberger, } \\
\text { Aptroot \& Honegger }\end{array}$ & $\mathrm{ZA}$ & P-360-II-a ${ }^{c}$ & AJ969609 & AM261281 \\
\hline T. arboricola & $X$. turbinata Vain. ${ }^{2}$ & $\mathrm{ZA}$ & $\mathrm{P}-3-\mathrm{I}^{\mathrm{d}}$ & AJ969509 & \\
\hline $\begin{array}{l}\text { T. decolorans } \\
\text { Ahmadjian }\end{array}$ & X. candelaria (L.) Th. Fr. ${ }^{3}$ & IS & P-205-II-a ${ }^{c}$ & AJ969569 & AM261272 \\
\hline T. decolorans & $\begin{array}{l}\text { Xanthomendoza hasseana } \\
\text { (Räsänen) Søchting, } \\
\text { Kärnefelt \& S.Y. Kondr. }{ }^{4}\end{array}$ & USA & P-400-Ia & AM159210 & \\
\hline T. decolorans & $X$. parietina & AUS & P-10-I- $\mathrm{a}^{\mathrm{c}}$ & AJ969515 & AM261258 \\
\hline T. decolorans & $X$. parietina & AUS & P-11-Ia & - & AM261259 \\
\hline T. decolorans & $X$. parietina & AUS & $\mathrm{L}-275-\mathrm{II}^{\mathrm{c}}$ & AJ969580 & AM261274 \\
\hline T. decolorans & X. parietina & USA & $\mathrm{L}-8^{\mathrm{c}}$ & A]969513 & AM261256 \\
\hline T. decolorans & $X$. parietina & USA & L- $-9^{c}$ & AJ969514 & AM261257 \\
\hline T. decolorans & $X$. parietina & $\mathrm{S}$ & P-97-I-a & AJ969539 & \\
\hline T. decolorans & X. parietina & $\mathrm{F}$ & P-121a-IIIb & A]969545 & AM261264 \\
\hline T. decolorans & X. parietina & $\mathrm{F}$ & P-121-I-b & AJ969549 & AM261266 \\
\hline T. decolorans & $X$. parietina & $\mathrm{F}$ & L-121-I-d & AJ969546 & AM261265 \\
\hline T. decolorans & X. parietina & $\mathrm{F}$ & P-121-II-c & A]969550 & AM261267 \\
\hline T. decolorans & X. parietina & $\mathrm{F}$ & P-121-II-g & - & AM261268 \\
\hline T. decolorans & X. parietina & $\mathrm{F}$ & P-144-III-b & A]969554 & \\
\hline T. decolorans & X. parietina & $\mathrm{F}$ & P-144-III-h & A]969556 & \\
\hline T. decolorans & $X$. parietina & $\mathrm{F}$ & L-145-III-g & AJ969557 & AM261270 \\
\hline T. decolorans & $X$. parietina & $\mathrm{F}$ & P-145-I-f-B & AJ969558 & AM261271 \\
\hline T. decolorans & X. parietina & $\mathrm{E}$ & P-280-IIa & A]969583 & AM261276 \\
\hline T. decolorans & $X$. parietina & $\mathrm{CH}$ & P-319-I-g ${ }^{c}$ & AJ970889 & AM261278 \\
\hline T. decolorans & $X$. parietina & $\mathrm{CH}$ & P-319-II-a & AJ969595 & \\
\hline T. decolorans & X. parietina & $\mathrm{CH}$ & P-320-I-d2 & A]969599 & \\
\hline T. decolorans & $X$. parietina & $\mathrm{CH}$ & P-320-II-b & AJ969600 & \\
\hline T. decolorans & $X$. parietina & $\mathrm{CH}$ & P-320-II-f & A]969603 & \\
\hline T. decolorans & X. polycarpa (Hoffm.) Rieber ${ }^{1}$ & USA & P-71-II-b & AJ969535 & AM261262 \\
\hline T. decolorans & $X$. polycarpa & $\mathrm{CH}$ & P-215-I-a & AJ969572 & \\
\hline $\begin{array}{l}\text { T. gelatinosa } \\
\text { Ahmadjian } \\
\text { ex Archibald }\end{array}$ & $\begin{array}{l}\text { Xanthomendoza weberi (S.Y. Kondr. } \\
\text { \& Kärnefelt) L. } \\
\text { Lindblom }^{5}\end{array}$ & USA & P-57-I-a & AJ969532 & AM261261 \\
\hline
\end{tabular}

${ }^{\text {a }} \mathrm{P}$ indicates photobiont isolated, L indicates whole-lichen DNA used for PCR amplification; ${ }^{\mathrm{b}}$ Trebouxia species identified according to ITS and $r b c \mathrm{~L}$ phylogenetic analysis (Nyati et al. submitted); ${ }^{\mathrm{c}}$ both introns present; ${ }^{\mathrm{d}}$ T. arboricola isolated from X. turbinata which had an insert of 1090 bases within 1512 group I intron. ${ }^{1}$ Xanthoria polycarpa (syn. Massjukiella polycarpa Fedorenko et al.); ${ }^{2}$ X. turbinata (syn. Xanthodactylon turbinatum (Vain.) C.W. Dodge); ${ }^{3} X_{5}$ candelaria (syn. Massjukiella candelaria Fedorenko et al.); ${ }^{4}$ Xanthomendoza hasseana (syn. Gallowayella hassiana Fedorenko et al.); ${ }^{5}$ Xanthomendoza weberi (syn. Honeggeria rosmariae Fedorenko et al.).

LSU, large subunit; SSU, small subunit; ITS, internal transcribed spacer.

LSU intron"). The second combined data set contained 33 DNA sequences of the S1512 intron with their corresponding rDNA host sequences ("Combined SSU intron").
Missing characters, gaps, and ambiguous sites were excluded in all phylogenetic analyses. For the visualization of phylogenetic results, distance trees were constructed by the 
TABLE 2. ITS and partial LSU accession numbers of reference algal strains used in this study.

\begin{tabular}{|c|c|c|c|c|}
\hline Algal species & Strain $^{\mathrm{a}}$ & LSU accession No. & ITS accession No. & Reference $^{\mathrm{b}}$ \\
\hline Asterochloris erici (Ahmadjian) Skaloud \& Peksa & UTEX 912 & & AF345441 & $\begin{array}{l}\text { Piercey-Normore and } \\
\text { DePriest (2001) }\end{array}$ \\
\hline A. erici & UTEX 910/IB 342 & AM261248 & & This study \\
\hline A. excentrica (Archibald) Skaloud \& Peksa & UTEX 1714/IB 345 & AM261249 & & This study \\
\hline A. glomerata (Warén) Skaloud \& Peksa & UTEX 897 & & AF345405 & $\begin{array}{l}\text { Piercey-Normore and } \\
\text { DePriest (2001) }\end{array}$ \\
\hline A. glomerata & UTEX 894/IB 349 & AM261252 & & This study \\
\hline A. italiana (Archibald) Skaloud \& Peksa & CCAP 219-5b/IB 358 & AM261253 & & This study \\
\hline $\begin{array}{l}\text { Chlorella angustoellipsoidea } \\
\text { N.Hanagata \& M.Chihara }\end{array}$ & C-87 & D17180 & & Aimi et al. (1994) \\
\hline Trebouxia anticipata Ahmadjian ex Archibald & UTEX 903/IB 340 & AM261247 & & This study \\
\hline T. arboricola & $92.011 \mathrm{~A} 1$ & & AJ249481 & Friedl et al. (2000) \\
\hline T. arboricola & $92.011 \mathrm{C} 3$ & & Z68703 & $\begin{array}{l}\text { Bhattacharya et al. } \\
\text { (1996b) }\end{array}$ \\
\hline T. arboricola ${ }^{\mathrm{c}}$ & SAG 219-Ia & & Z68705 & $\begin{array}{l}\text { Bhattacharya et al. } \\
\text { (1996b) }\end{array}$ \\
\hline T. asymmetrica Friedl \& Gärtner & B207 & & AF344177 & Beck et al. (2002) \\
\hline T. corticola (P.A.Archibald) Gärtner & UTEX 909 & & AJ249566 & Friedl et al. (2000) \\
\hline T. decolorans & UTEX 901/IB 327 & AM261243 & Unpublished & Unpublished \\
\hline T. galapagensis (Hildreth \& Ahmadjian) Gärtner & UTEX 2230 & & AJ249567 & Friedl et al. (2000) \\
\hline T. gelatinosa & $87.072 \mathrm{~B} 1$ & & AJ249575 & Friedl et al. (2000) \\
\hline T. higginsiae (Hildreth \& Ahmadjian) Gärtner & UTEX 2232 & & AJ249574 & Friedl et al. (2000) \\
\hline T. impressa Ahmadjian & $87.017 \mathrm{E} 1$ & & AJ249570 & Friedl et al. (2000) \\
\hline T. showmanii (Hildreth \& Ahmadjian) Gärtner & UTEX 2234/IB 337 & AM261246 & AF242470 & Kroken et al. (2000) \\
\hline
\end{tabular}

${ }^{\text {a} I B: ~ C u l t u r e ~ c o l l e c t i o n ~ o f ~ a l g a e ~ a t ~ t h e ~ U n i v e r s i t y ~ o f ~ I n n s b r u c k ; ~ S A G: ~ A l g a l ~ c u l t u r e ~ c o l l e c t i o n, ~ U n i v e r s i t y ~ o f ~ G o ̈ t t i n g e n ; ~ U T E X: ~}$ algal culture collection, University of Texas.

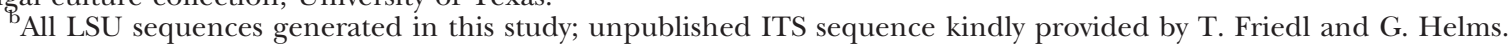

${ }^{\mathrm{c}}$ Type strain of the genus Trebouxia.

TABLE 3. List of newly designed primers used in this study.

\begin{tabular}{lllrr}
\hline \hline Primer & \multicolumn{1}{c}{ Target } & Sequence $\left(5^{\prime} \rightarrow 3^{\prime}\right)$ & Position & Relative to accession \\
\hline Intron 1 (fwd) & SSU intron & CTGTCACTAGACTGAGTGC & 208 & AM159503 \\
Intron 2 (rev) & SSU intron & CCAGTTTAGAGGCTCGAATC & 601 & AM159503 \\
Intron 3 (rev) & SSU intron & GGWCCGACTATATCTTAAGC & 1716 & AJ969509 \\
Intron 4 (fwd) & SSU intron & TTGTTGTAAAGGGCTCGACT & 709 & AJ969509 \\
Intron 5 (rev) & SSU intron & ACTCCTGTAAGCTCTCCTTCC & 1756 & AJ969509 \\
LSU fwd & LSU & TTTAACACCCATGAGACGCAAGTAAC & 684 & D17810 \\
LSU rev & LSU & GCCTTAACTCAGCTTTCGGTTCA & 1607 & D17810 \\
\hline
\end{tabular}

neighbor-joining algorithm implemented in molecular evolutionary genetics analysis (MEGA) version 5 (Tamura et al. 2007) and annotated with support values from Bayesian and ML analyses as well as with support values from 500 bootstraps using the neighbor-joining algorithm in MEGA.

\section{RESULTS AND DISCUSSION}

Trebouxia L798 group I intron. In the current investigation, 28 LSU rDNA group I introns were found, which are all inserted at position L798 and belong to group IB introns (Fig. 2). In a secondary structure-based alignment of Trebouxia LSU introns, the sequence of Chlorella angustoellipsoidea C-87 was included (Aimi et al. 1994) because this intron was also 445 base pairs (bp) in length and had all the characteristic RNA folding (P1-P10) properties of group IB introns (Burke et al. 1987). The flanking exon regions were also highly conserved.
The L798 group I intron phylogeny (Fig. 3) showed a similar grouping of taxa into clades as the ITS host cell tree (Fig. 1), indicating vertical inheritance of the intron. The only exception was the intron of $T$. showmanii (Figs. 1 and 3), which was placed in the "arboricola" clade, indicating the possibility of lateral transfer. A comparison of the conserved core catalytic sequences $(P, Q, R, S)$ revealed high similarity with multiple nucleotide substitutions between Trebouxia subclades and the Asterochloris clade (Table 4). Moreover, an incongruent length difference test rejected the hypothesis of homogeneity among intron and host data sets $(P=0.005)$. Due to the conserved secondary structures among the LSU group I intron of representatives of the genera Trebouxia and Asterochloris (Microthamniales) and of C. angustoellipsoidea (Chlorellales; Table 4), we hypothesize that this intron was present in the common ancestor of the genera Trebouxia and Asterochloris. 


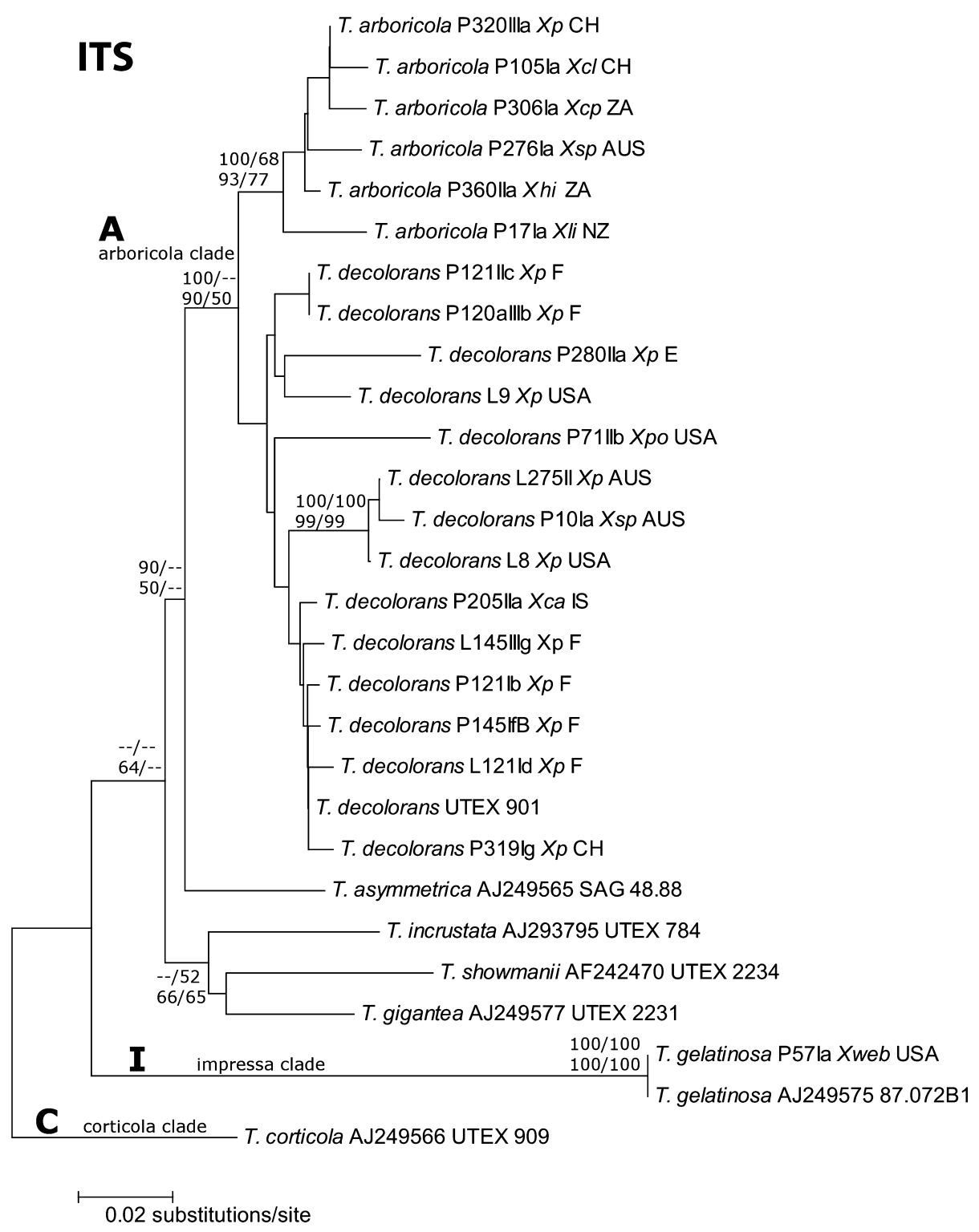

FIG. 1. Phylogeny of Trebouxia s. lat. Sequences obtained from GenBank are indicated in Table 3. Support values shown at a respective node are posterior probabilities of nodes from Bayesian analysis in MrBayes (first row, first number), values from 100 bootstrap replicates in a maximum likelihood (ML) analysis in Paup (first row, second number), values from 500 bootstrap replicates in a neighbor-joining analysis in molecular evolutionary genetics analysis (second row, first number), and maximum parsimony support values from 100 bootstraps generated with phylogenetic analysis using parsimony (second row, second number). Clades A, I, and C represent "arboricola", "impressa", and "corticola", respectively, as proposed by Helms (2003). The identity of photobionts was inferred on the basis of internal transcribed spacer (ITS) and $r b c \mathrm{~L}$ phylogenetic analyses including reference strains (Nyati, Scherrer, Werth, and Honegger, in press). Abbreviations used: Xca, Xanthoria candelaria; Xcl, X. calcicola; Xcp, X. capensis; Xec, X. ectaneoides; Xh, X. hirsuta; Xli, X. ligulata; Xp, X. parietina; Xpo, X. polycarpa; Xtu, X. turbinata; Xsp, Xanthoria sp.; Xweb, Xanthomendoza weberi. Phylogeny of the nuclear ribosomal internal transcribed spacer region (complete ITS region, including the 5.8S rRNA gene) as inferred using ML analysis. Asterochloris sequences not used in analyses due to very high-sequence divergence.

Trebouxia $S 1512$ group I intron. Intron-specific primers were used for PCR amplification reactions, which were carried out with genomic DNA isolated from algal strains and from whole-lichen DNA extracts. Several different primer combinations were used to exclude PCR bias. These tests were done to infer the frequencies of introns in the investigated algal isolates. Of the 124 nrDNA sequences generated for Trebouxia photobionts of Xanthoria s. lat and Xanthomendoza spp., 32 contained a group I intron. The intron-harboring Trebouxia photobionts belonged to the "arboricola" clade A as described by Helms (2003). In all photobiont samples except for one, the intron varied between 434 and $530 \mathrm{bp}$ in length. The $460 \mathrm{bp}$ intron of the T. arboricola photobiont of the African X. turbinata (accession no. AJ969509) had an additional insertion of 1,090 bp at a conserved site, making the entire intron 


\section{Trebouxia decolorans (IB 327) Group I Intron \\ Position L798}

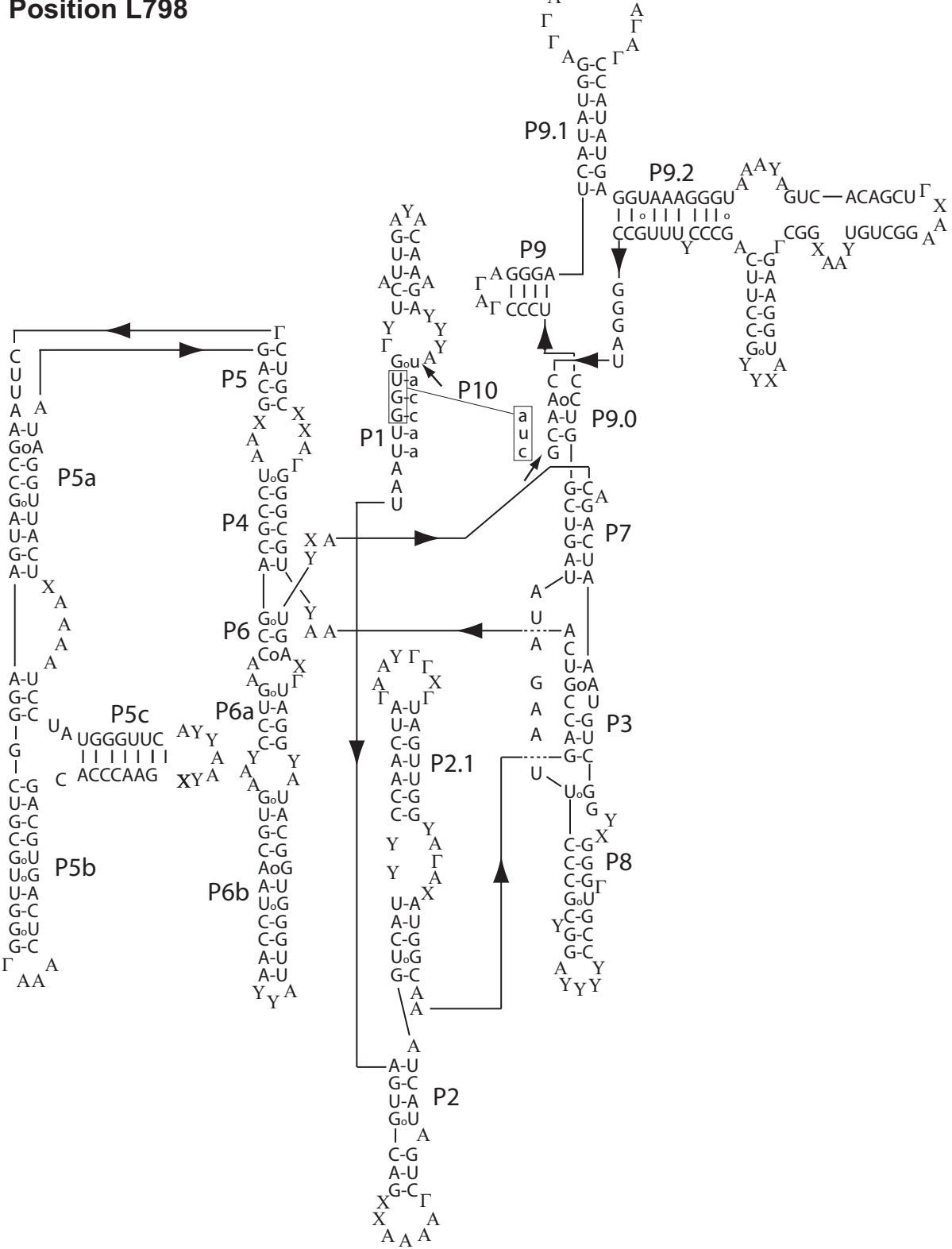

FIG. 2. Putative secondary structure of the group I intron within the large subunit rRNA precursor of Trebouxia decolorans UTEX 901 drawn according to the conventions of Cech et al (1994). Arrows point to the $5^{\prime}$ and $3^{\prime}$ splice junctions of this L798 group I intron. Also shown are the locations of the pairing segments P1-P10. The solid lines are used to position secondary structure elements that are believed to interact in close proximity. sequence $1,550 \mathrm{bp}$ in length. Although this intron is very long, it does encode an ORF for a homing endonuclease as assessed by blast searches (Altschul et al. 1997). No similarities were found between this longer intron and complex nested inserts found in 18S rDNA of ascomycetes, where putative spliceosomal introns were inserted within group I introns (DePriest and Been 1992, Myllys et al. 1999, DePriest 2004).

In comparison with published data (Bhattacharya et al. 1996b), all insertions at position 1,512 were identified as group I introns. Twenty-nine newly generated intron sequences together with available data were analyzed using phylogenetic methods (Figs. 3 and 4) and compared with the ITS phylogeny (Fig. 1) to identify potential cases of lateral transfer (Bhattacharya et al. 1996b, Friedl et al. 2000). The ITS and S1512 group I intron phylogenies showed a similar grouping of clades (Figs. 1 and 4), indicating overall vertical inheritance. However, incongruence length difference tests suggested that the data sets were not homogeneous $(P=0.001)$. Indeed, three interesting incongruities were found among host and intron phylogenies (marked with arrowheads in Fig. 4): (i) the intron sequence of $T$. corticola (UTEX 909, a putatively free-living alga from tree bark in Webster, MA, 
TABLE 4. Comparison of catalytic core (PQRS) sequences of LSU 798 group I introns in representatives of the genera Trebouxia s. str. and Asterochloris. The identity of photobionts of the investigated Xanthoria and Xanthomendoza species was inferred on the basis of ITS and $r b c \mathrm{~L}$ analyses. The positions of $\mathrm{P}, \mathrm{Q}, \mathrm{R}$, and $\mathrm{S}$ regions are based on the reference sequence of the Chlorella angustoellipsoidea strain C-87 intron (accession number D17180).

\begin{tabular}{|c|c|c|c|c|}
\hline & $\mathrm{P}$ & $\mathrm{Q}$ & $\mathrm{R}$ & $\mathrm{s}$ \\
\hline T. decolorans & AAUUGCGGGGAC & AAUCCGCAGC & GUUCACAGACUAAA & AAGAUAUAGUCG \\
\hline L145IIIg Xp F & AAUUGCGGGGAC & AAUCCGCAGC & GUUCACAGACUAAA & AAGAUAUAGUCG \\
\hline L121Id Xp F & AAUUGCGGGGAC & AAUCCGCAGC & GUUCACAGACUAAA & AAGAUAUAGUCG \\
\hline P121IIg Xp F & AAUUGCGGGGAC & AAUCCGCAGC & GUUCACAGACUAAA & AAGAUAUAGUCG \\
\hline P145IdfB Xp F & AAUUGCGGGGAC & AAUCCGCAGC & GUUCACAGACUAAA & AAGAUAUAGUCG \\
\hline P319Ig Xp CH & AAUUGCGGGGAC & AAUCCGCAGC & GUUCACAGACUAAA & AAGAUAUAGUCG \\
\hline P120aIIIb Xp F & AAUUGCGGGGAC & AAUCCGCAGC & GUUCACAGACUAAA & AAGAUAUAGUCG \\
\hline P121II cd Xp F & AAUUGCGGGGAC & AAUCCGCAGC & GUUCACAGACUAAA & AAGAUAUAGUCG \\
\hline P280IIa Xp E & AAUUGCGGGGAC & AAUCCGCAGC & GUUCACAGACUAAA & AAGAUAUAGUCG \\
\hline P205IIa Xca IS & AAUUGCGGGGAC & AAUCCGCAGC & GUUCACAGACUAAA & AAGAUAUAGUCG \\
\hline P121Ib Xp F & AAUUGCGGGGAC & AAUCCGCAGC & GUUCACAGACUAAA & AAGAUAUAGUCG \\
\hline P71IIb Хро USA & AAUUGCGGGGAC & AAUCCGCAGC & GUUCACAGACUAGA & AAGAUAUAGUCG \\
\hline L9 Xp USA & AAUUGCGGGGAC & AAUCCGCAGC & GUUCACAGACUAAA & AAGAUGUAGUCG \\
\hline L8 Xp USA & AAUUGCGGGGAC & AAUCCGCAGC & GUUCACAGACUAAA & AAAAUAUAGUCG \\
\hline L275II Xp USA & AAUUGCGGGGAC & AAUCCGCAGC & GUUCACAGACUAAA & AAAAUAUAGUCG \\
\hline P11Ia Xp AUS & AAUUGCGGGGAC & AAUCCGCAGC & GUUCACAGACUAAA & AAAAUAUAGUCG \\
\hline P10Ia Xsp AUS & AAUUGCGGGGAC & AAUCCGCAGC & GUUCACAGACUAAA & AAAAUAUAGUCG \\
\hline P306Ia Xср ZA & AAUUGCGGGGAC & AAUCCGCAGC & GUUCACAGACUAAA & AAGAUAUAGUCG \\
\hline P360IIa Xhi ZA & AAUUGCGGGGAC & AAUCCGCAGC & GUUCACAGACUAAA & AAGAUAUAGUCG \\
\hline P105Ia Xcl CH & AAUUGCGGGGAC & AAUCCGCAGC & GUUCACAGACUAAA & AAGAUAUAGUCG \\
\hline P276Ia Xsp ZA & AAUUGCGGGGAC & AAUCCGCAGC & GUUCACAGACUAAA & AAGAUAUAGUCG \\
\hline P320IIIa Xp CH & AAUUGCGGGGAC & AAUCCGCAGC & GUUCACAGACUAAA & AAGAUAUAGUCG \\
\hline P17Ia Xli NZ & AAUUGCGGGGAC & AAUCCGCAGC & GUUCACAGACUAAA & AAGAUAUAGUCG \\
\hline T. showmanii & AAUUGCGGGGAC & AAUCCGCAGC & GUUCACAGACUACA & AAGAUAUAGUCG \\
\hline T. anticipata & AAUUGCGGGGAC & AAUCCGCAGC & GUUCACAGACUAAA & AAGAUAUAGUCG \\
\hline P 57 Ia Xweb U & AAUUGCGGGGAC & AAUCCGCAGC & GUUCACAGACUAAA & AAGAUAUAGUCG \\
\hline T. glomerata & AAUUGCCGGGAC & AAUCGGCAGC & GUUCACAGACUAGA & AAGGUAUAGUCG \\
\hline T. italiana & AAUUGCCGGGAC & AAUCGGCAGC & GUUCACAGACUAGA & AAGAUAUAGUCG \\
\hline T. excentrica & AAUUGCCGGGAC & AAUCGGCAGC & GUUCACAGACUAGA & AAGAUAUAGUCG \\
\hline T. erici & AAUUGCCGGGAC & AAUCGGCAGC & GUUCACAGACUAGA & AAGAUAUAGUCG \\
\hline C. angustoellipsoidea & AAUUGCGGGAAA & AAUCCGCAGC & GUUCACAGACUAGA & AAGGUAUAGUCG \\
\hline
\end{tabular}

USA, isolated by V. Ahmadjian in 1959), a representative of the "corticola" clade $\mathrm{C}$ according to Helms (2003), falls near three intron sequences from clade A. These $T$. decolorans photobionts were identified from X. parietina thalli from Barossa valley (Australia) and Sonoma County (CA, USA) and from an unnamed Xanthoria species from Tasmania (Australia). (ii) The intron sequence of T. impressa (Friedl et al. 2000), a representative of the "impressa" clade I according to Helms (2003), falls near two T. decolorans intron sequences from clade A. These T. decolorans photobionts were found in thalli of $X$. parietina and Xanthomendoza hasseana in California. (iii) Intron sequences of $T$. arboricola isolates from $X$. ectaneoides (Sicily, Italy), X. parietina (Avenches, Switzerland), $X$. polycarpa (Otago, New Zealand), and X. turbinata (Port Nolloth, South Africa) formed a separate group outside the group of samples belonging to $T$. decolorans, receiving high support in all three analyses (Fig. 4). All these incongruities are likely to have resulted from intron lateral transfers.

LSU and SSU group I intron distribution in Trebouxia and Asterochloris spp. Introns in both SSU and LSU rDNA were found in only nine Trebouxia isolates. The distribution of these taxa in the photobionts of Xanthoria s. lat. (Table 1) and in the host tree (Table 2) follows neither a geographic nor a taxo- nomic pattern. Trebouxia isolates from thalli of $X$. parietina from the Northern Hemisphere are, however, overrepresented in this analysis, and only one sample was studied from some of the other species. In a survey of the genetic diversity among Trebouxia photobionts of Teloschistaceae $(n=124)$, the S1512 group I intron was found in $50 \%$ of $T$. arboricola, but in only $23 \%$ of T. decolorans samples (Nyati et al. 2014). Friedl et al. (2000) found a S1512 intron in $28 \%$ of 85 algal strains that were tested. In a PCR-based screening of sterile cultured isolates of $T$. arboricola or T. decolorans, respectively, from populations of X. parietina and X. ectaneoides from maritime, coastal, rural, and urban sites (for details see Itten and Honegger 2010), a very unequal distribution of S1512 group I introns was observed among populations, ranging from none to $87 \%$ (Table 5). The percentage distribution of introns was assessed by combining sequences obtained from several photobiont isolates from within a single lichen thallus as well as from a number of different lichen thalli within a population. This result may reflect the dynamic nature of intron gain and loss. Very high genetic diversity by RADPPCR fingerprinting has been observed from the axenically cultured mycobiont isolates from the same populations (Itten and Honegger 2010). The 


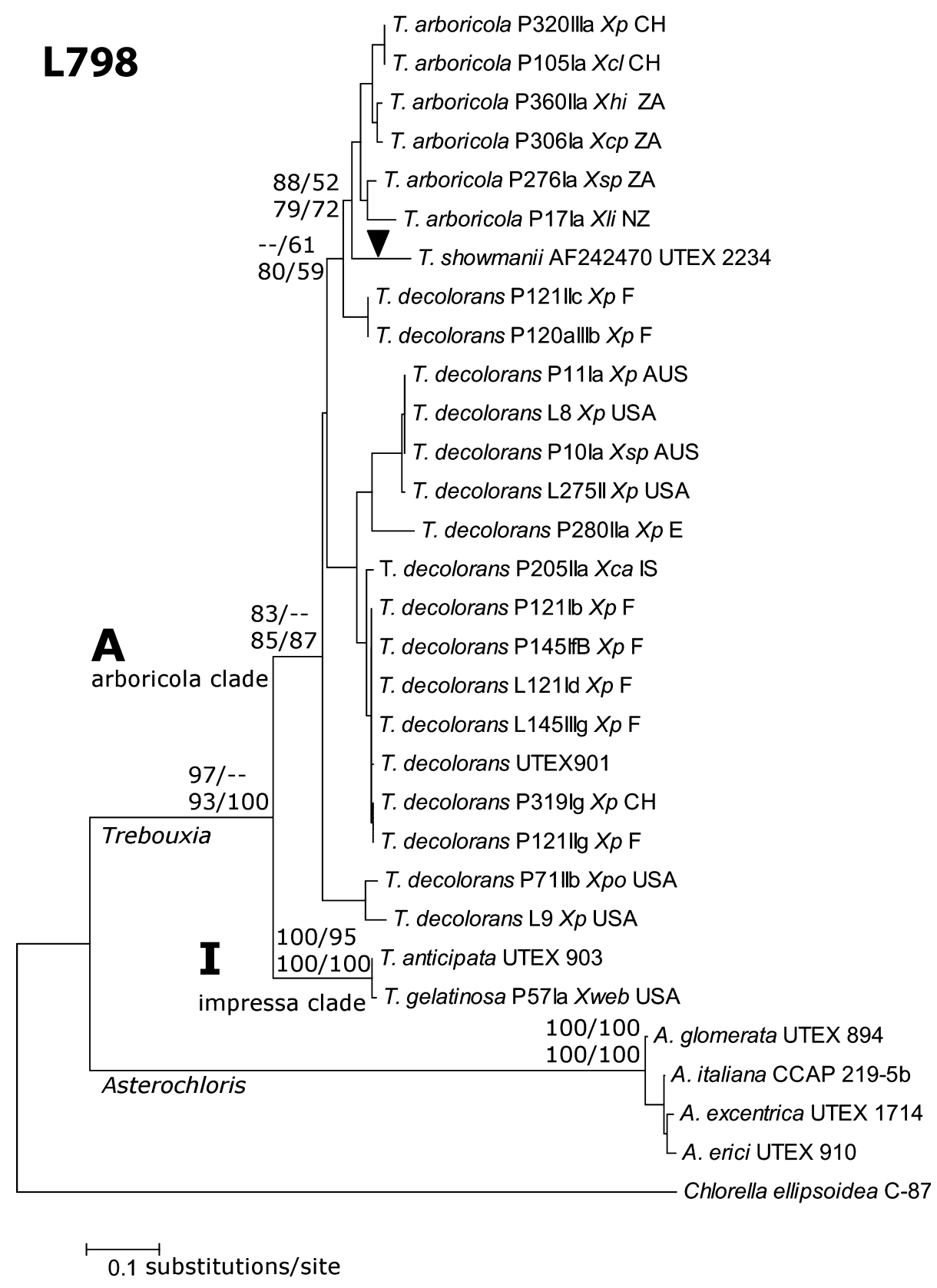

FIg. 3. Phylogeny of the large subunit 798 group I intron in representatives of Trebouxia s. str. and Asterochloris Tscherm.-Woess. An intron sequence of Chlorella angustoellipsoidea strain C-87 was obtained from GenBank (accession D17810) and used as outgroup taxon. Arrowhead indicates potential site for lateral intron transfer. All the support values were generated as in Figure 2.
Trebouxia photobionts of X. ectaneoides or X. parietina populations with the highest and lowest percentages of S1512 group I introns were collected less than $1 \mathrm{~km}$ apart from each other. The first was found on granite rock in the supralittoral fringe of a tiny island (Île verte), the other on shrubs in the old port of Roscoff in Brittany (NW France; Table 5). However, we cannot exclude that recombination could redistribute introns among individual algal cells in free-living populations of Trebouxia, followed by gene flow, which would lead to the same pattern of intron distribution in populations.

Introns of lichen photobionts and mycobionts. The origin of S1512 group I introns in chlorophytes is still a matter of debate. Based on the observation of a close phylogenetic relationship of the S1512 group I intron lineage in chlorophytes to viral introns found in Chlorella spp., the viruses were hypothesized to be either the source or at least the vector, which facilitates the spread of group I introns among eukaryotes (Aimi et al. 1994, Bhattacharya et al. 1996b).

Horizontal transfer of group I introns is known from many biological systems. Examples of interkingdom transfers are as follows: (i) plant parasitic fungus to host plant (Nishida and Sugiyama 1995, Vaughn et al. 1995, Sanchez-Puerta et al. 2008); (ii) fungus to green alga (Lindstrom and Pistolic 2005); 


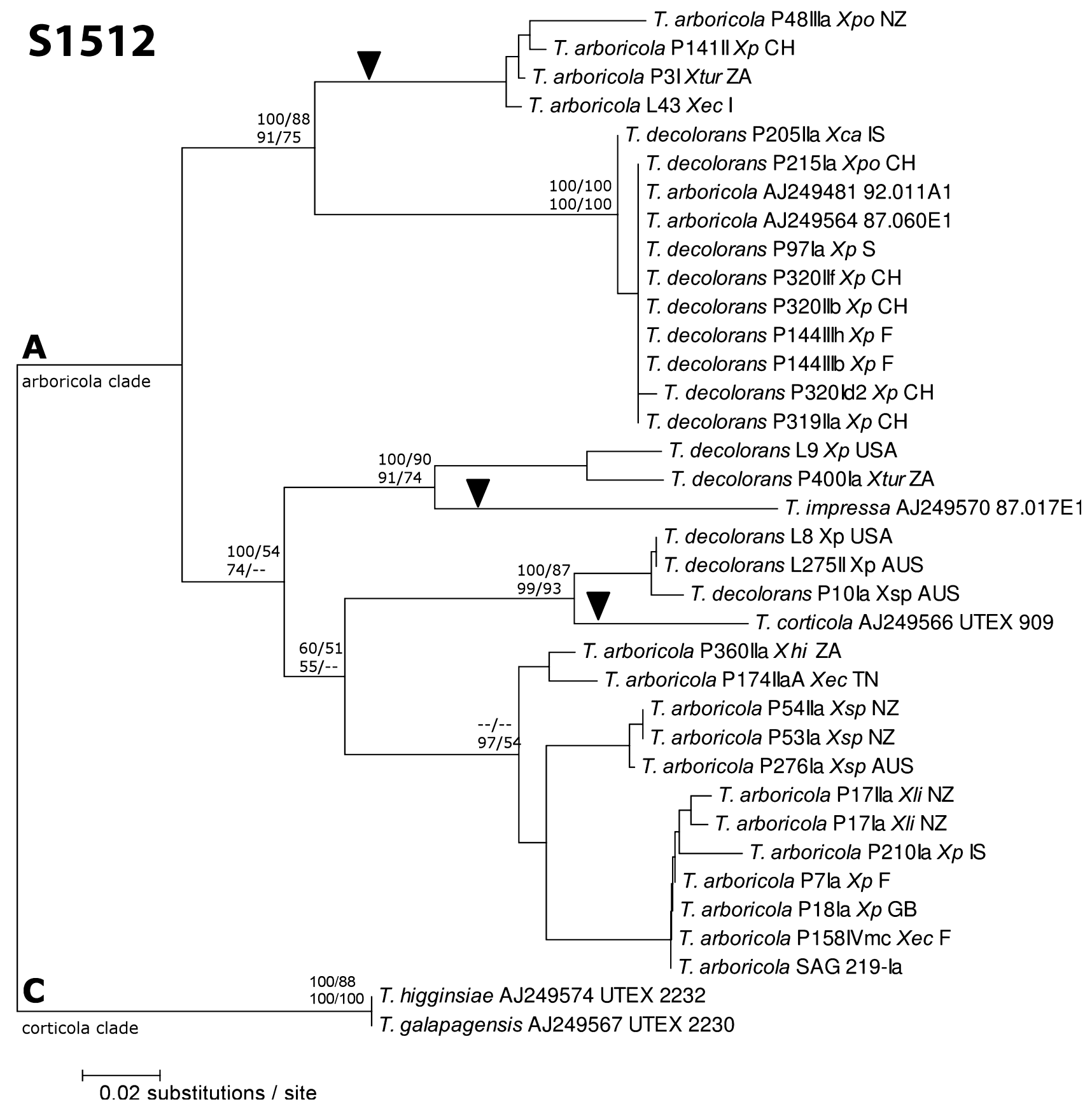

FIG. 4. Phylogeny of the small subunit 1,512 group I intron in representatives of Trebouxia s. str. All the support values were generated as in Figure 2.

(iii) fungus to red alga (Müller et al. 2005); (iv) red alga to brown alga (Bhattacharya et al. 2001); (v) algae to amoebae (Turmel et al. 1995); and (vi) between eubacteria and chloroplasts (Kuhsel et al. 1990). Interorganellar transfer of group I introns has been shown from mitochondria to the nucleus (Curtis and Archibald 2010), and from mitochondria to the chloroplast (Pombert et al. 2005). Interfamilial transfers among lichen-forming ascomycetes within the Physciaceae were described by Simon et al. (2005). Based on the close relationship of introns in green algal lichen photobionts with bacterial and fungal introns, del Campo et al. (2009) proposed lichen thalli to be potential sites of horizontal transfer of introns. Indeed, already in the Lower Devonian ( $415 \mathrm{Myr}$ ago) were the thalli of lichenforming fungi microcosms, built up by the quantitatively predominant lichen-forming fungus and its photoautotrophic green algal or cyanobacterial partner, but comprising also large numbers of epiand endolichenic bacteria and nonlichenized fungi, all in close physical contact with the lichen 
TABLE 5. Presence of SSU1512 group I intron in axenically cultured Trebouxia isolates from five Xanthoria populations collected in Europe.

\begin{tabular}{|c|c|c|c|c|c|}
\hline Photobiont & Voucher No. & Mycobiont & Collecting site & Substrate & Intron $^{\mathrm{a}} /$ isolates, $\%$ \\
\hline Trebouxia arboricola & 158 & $X$. ectaneoides & Maritime, $\mathrm{F}$ & Saxicolous & $20 / 23,87 \%$ \\
\hline T. decolorans & $120-121$ & $X$. parietina & Rural, F & Epiphytic & $1 / 25,4 \%$ \\
\hline T. decolorans & $144-145$ & $X$. parietina & Rural, F & Epiphytic & $6 / 63,9.5 \%$ \\
\hline T. decolorans & 164 & X. parietina & Coastal, F & Epiphytic & $0 / 12,0 \%$ \\
\hline T. arboricola, T. decolorans & $319-320$ & $X$ parietina & Urban, $\mathrm{CH}^{\mathrm{b}}$ & Epiphytic, saxicolous & $18 / 47,38 \%$ \\
\hline
\end{tabular}

${ }^{\text {a }}$ Presence of intron tested with PCR assays.

${ }^{\mathrm{b}}$ All $T$. decolorans isolates were photobiont of epiphytic samples, whereas $T$. arboricola was identified from saxicolous specimens. F, France; CH, Switzerland.

Details about these Xanthoria populations are found in Itten and Honegger (2010).

mycobiont and partly also with the photobiont (Honegger et al. 2013 a,b); inserts made in list of references), as is the case in extant lichens (Honegger 2012). However, no direct evidence has yet been reported demonstrating SSU rDNA group I intron movement between the fungal and algal partners in the lichen symbiosis.

Only few insertion positions (S516, S943, S1046, and S1506) for group I introns are found in both green algae and ascomycetes (Gargas et al. 1995b). The SSU intron at position S1512, which is present on the surface of the mature ribosome in tertiary structure, is restricted to green algae (Gargas et al. 1995a,b); it has never been found in fungi or other organisms. DePriest and Been (1992) concluded that group I introns of lichen algae do not originate from their respective fungal partners or vice versa. Bhattacharya et al. (2002) demonstrated that there is no evolutionary relationship between group I introns of lichen-forming ascomycetes and their green algal partners; thus, horizontal transfer can be excluded. One process that might lead to a similar pattern of intron distribution as observed in our study is photobiont switching (Piercey-Normore and DePriest 2001, Nelsen and Gargas 2008, 2009). Photobiont switches could occur if a developing germling incorporates either a free-living alga, or an alga that has been released from a thallus, e.g., after being digested by invertebrates. Algal cells have been shown to survive the gut passage of mites (Meier et al. 2002) and snails (Boch et al. 2011), providing an opportunity for algal uptake by developing germlings. Friedl et al. (2000) suggested that lichenization might facilitate the spread of 1,512 introns among algal strains that coexist in fungal thalli. However, it is difficult to imagine how intron gain might proceed within the lichen thallus. In morphologically advanced, foliose, or fruticose lichens, the algal cells have physical contact only with sister cells derived from the same mother cell, but each of them is in direct contact with the fungal partner via the appressorial or haustorial complex (Honegger 1991). A mycobiont-derived, waterrepellent wall surface layer composed of hydrophobins and/or other hydrophobic wall surface components (Scherrer et al. 2000) ensheaths the algal and fungal surfaces in the thalline interior (Honegger 1991, 2001). During the regular wetting and drying cycles, solutes are passively exchanged underneath this hydrophobic sealing via the apoplastic continuum of both partners, but it seems unlikely that mobile genetic elements would be transmitted through this process. It is conceivable that intron gain occurs while lichen photobionts are not symbiotic, but free living and in contact with cells of other species or strains. The example of the S1512 group I intron of the type strain of T. cortico$l a$, as reported in this study, is consistent with this idea. This strain was isolated from putatively free-living cells, not from a lichen, and its intron is similar to that in $T$. decolorans isolates from a different clade, the "arboricola" clade A (i.e., Helms 2003). According to the literature, T. arboricola, the type species of the genus and photobiont of numerous lichen-forming ascomycetes, including Teloschistaceae, is also a common and widespread free-living alga (Ettl and Gärtner 1995, Beck et al. 1998, John et al. 2002, Rindi and Guiry 2003), despite contradictory claims (Ahmadjian 1988). The mechanisms underlying intron gain in lichen photobionts merit therefore a thorough investigation in future studies.

Our sincere thanks go to Prof. Georg Gärtner, Innsbruck, for generous gifts of reference strains, and to the Swiss National Science Foundation for financial support (grant no. 31-103860/1 to R.H.). D.B. acknowledges generous support from the National Science Foundation and the National Institutes of Health (grants EF 04-31117 and R01 ES013679, respectively).

Ahmadjian, V. 1988. The lichen alga Trebouxia - does it occur free-living. Plant Syst. Evol. 158:243-7.

Aimi, T., Yamada, T., Yamashita, M. \& Murooka, Y. 1994. Characterization of the nuclear large subunit ribosomal RNA encoding gene and the group-I self splicing intron from Chlorella ellipsoidea C-87. Gene 145:139-44.

Altschul, S. F., Madden, T. L., Schäffer, A. A., Zhang, J., Zhang, Z., Miller, W. \& Lipman, D. J. 1997. Gapped BLAST and PSIBLAST: a new generation of protein database search programs. Nucleic Acids Res. 25:3389-402.

Bachar, D., Guillou, L. \& Christen, R. 2013. Detection of introns in eukaryotic small subunit ribosomal RNA gene sequences. Dataset Papers Biol. 2013:12.

Beck, A., Friedl, T. \& Rambold, G. 1998. Selectivity of photobiont choice in a defined lichen community: inferences from cultural and molecular studies. New Phytol. 139:709-20. 
Beck, A., Kasalicky, T. \& Rambold, G. 2002. Myco-photobiontal selection in a Mediterranean cryptogam community with Fulgensia fulgida. New Phytologist 153:317-26.

Bhattacharya, D., Cannone, J. J. \& Gutell, R. R. 2001. Group I intron lateral transfer between red and brown algal ribosomal RNA. Curr. Genet. 40:82-90.

Bhattacharya, D., Damberger, S., Surek, B. \& Melkonian, M. 1996a. Primary and secondary structure analyses of the rDNA group-I introns of the Zygnematales (Charophyta). Curr. Genet. 29:282-6.

Bhattacharya, D., Friedl, T. \& Damberger, S. 1996b. Nuclearencoded rDNA group I introns: origin and phylogenetic relationships of insertion site lineages in the green algae. Mol. Biol. Evol. 13:978-89.

Bhattacharya, D., Friedl, T. \& Helms, G. 2002. Vertical evolution and intragenic spread of lichen-fungal group I introns. J. Mol. Evol. 55:74-84.

Bhattacharya, D., Surek, B., Rusing, M., Damberger, S. \& Melkonian, M. 1994. Group I introns are inherited through common ancestry in the nuclear encoded ribosomal RNA of Zygnematales (Charophyceae). Proc. Nat. Acad. Sci. USA 91:9916-20.

Bhattacharya, D., Weber, K., An, S. S. \& Berning-Koch, W. 1998. Actin phylogeny identifies Mesostigma viride as a flagellate ancestor of the land plants. J. Mol. Evol. 47:544-50.

Boch, S., Prati, D., Werth, S., Rüetschi, J. \& Fischer, M. 2011. Lichen endozoochory by snails. PLoS ONE 6:e18770.

Burke, J. M., Belfort, M., Cech, T. R., Davies, R. W., Scweyen, R. J., Shub, D. A., Szostak, J. W. \& Tabak, H. F. 1987. Structural conventions for group I introns. Nucleic Acids Res. 15:7217-21.

del Campo, E. M., Casano, L. M., Gasulla, F. \& Barreno, E. 2009. Presence of multiple group I introns closely related to bacteria and fungi in plastid 23S rRNAs of lichen-forming Trebouxia. Int. microbiol. J. Spanish Soc. Microbiol. 12:59-67.

Cech, T. R. 1988. Conserved sequences and structures of Group-I introns - building an active-site for RNA catalysis - a review. Gene 73:259-71.

Cech, T. R., Damberger, S. H. \& Gutell, R. R. 1994. Representation of the secondary and tertiary structure of Group-I Introns. Nat. Struct. Biol. 1:273-80.

Curtis, B. A. \& Archibald, J. M. 2010. A spliceosomal intron of mitochondrial DNA origin. Curr. Biol. 20:R919-20.

Del Campo, E. M., Casano, L. M., Gasulla, F. \& Barreno, E. 2010a. Suitability of chloroplast LSU rDNA and its diverse group I introns for species recognition and phylogenetic analyses of lichen-forming Trebouxia algae. Mol. Phylogenet. Evol. 54:437-44.

Del Campo, E. M., Gimeno, J., De Nova, J. P. G., Casano, L. M., Gasulla, F., García-Breijo, F., Reig-Armiñana, J. \& Barreno, E. 2010b. South European populations of Ramalina farinacea (L.) Ach. share different Trebouxia algae. In Thomas Nash III; Linda Geiser; Bruce McCune; Dagmar Triebel; Alexandru M. Tomescu; William Sanders [Ed.] Biology of Lichens Symbiosis, Ecology, Environm. Monitoring, Systematics, Cyber Applications. Schweizerbart science publishers, Stuttgart, Germany, pp. $247-56$.

DePriest, P. T. 1993. Small subunit rDNA variation in a population of lichen fungi due to optional group I introns. Gene 134:67-74

DePriest, P. T. 2004. Early molecular investigations of lichenforming symbionts: 1986-2001. Annu. Rev. Microbiol. 58: 273-301.

DePriest, P. T. \& Been, M. D. 1992. Numerous group I introns with variable distributions in the ribosomal DNA of a lichen fungus. J. Mol. Biol. 228:315-21.

Drummond, A., Suchard, M. A., Xie, D. \& Rambaut, A. 2012. Bayesian phylogenetics with BEAUti and the BEAST 1.7. Mol. Biol. Evol. 29:1969-73.

Dujon, B. 1989. Group I introns as mobile genetic elements: facts and mechanistic speculations - a review. Gene 82:91-\&.

Einvik, C., Elde, M. \& Johansen, S. 1998. Group I twintrons: genetic elements in myxomycete and schizopyrenid amoeboflagellate ribosomal DNAs. J. Biotechnol. 64:63-74.
Ettl, H. \& Gärtner, G. 1995. Syllabus der Boden-, Luft-und Flechtenalgen. Gustav Fischer, Stuttgart, Germany.

Farris, J. S., Källersjö, M., Kluge, A. G. \& Bult, C. 1995. Testing significance of incongruence. Cladistics 10:315-9.

Friedl, T., Besendahl, A., Pfeiffer, P. \& Bhattacharya, D. 2000. The distribution of group I introns in lichen algae suggests that lichenization facilitates intron lateral transfer. Mol. Phylogenet. Evol. 14:342-52.

Gargas, A., Depriest, P. T., Grube, M. \& Tehler, A. 1995a. Multiple origins of lichen symbioses in fungi suggested by SSU rDNA phylogeny. Science 268:1492-5.

Gargas, A., Depriest, P. T. \& Taylor, J. W. 1995b. Positions of multiple insertions in SSU rDNA of lichen-forming fungi. Mol. Biol. Evol. 12:208-18.

Gutierrez, G., Blanco, O., Divakar, P. K., Lumbsch, H. T. \& Crespo, A. 2007. Patterns of group I intron presence in nuclear SSU rDNA of the lichen family Parmeliaceae. J. Mol. Evol. 64:181-95.

Harris, L. B. \& Rogers, S. O. 2011. Evolution of small putative group I introns in the SSU rRNA gene locus of Phialophora species. BMC Res. Notes 4:258.

Haugen, P., Simon, D. M. \& Bhattacharya, D. 2005a. The natural history of group I introns. Trends Genet. 21:111-9.

Haugen, P., Wikmark, O.-G., Vader, A., Coucheron, D. H., Sjøttem, E. \& Johansen, S. D. 2005b. The recent transfer of a homing endonuclease gene. Nucleic Acids Res. 33:2734-41.

Helms, G. 2003. Taxonomy and symbiosis in associations of Physciaceae and Trebouxia. PhD thesis, University of Göttingen, Göttingen, Germany, 156 pp.

Honegger, R. 1991. Functional aspects of the lichen symbiosis. Ann. Rev. Plant Physiol. Mol. Biol. 42:553-78.

Honegger, R. 2001. The symbiotic phenotype of lichen-forming ascomycetes. In Hock, B. [Ed.] Fungal Associations. Springer, Berlin, pp. 165-88.

Honegger, R. 2003. The impact of different long-term storage conditions on the viability of lichen-forming ascomycetes and their green algal photobiont. Trebouxia spp. Plant Biol. 5:324-30.

Honegger, R. 2012. Differential gene expression within the cyanobacterial cell population of a lichen thallus. New Phytol. 196:657-60.

Honegger, R., Edwards, D. \& Axe, L. 2013a. The earliest records of internally stratified cyanobacterial and algal lichens from the Lower Devonian of the Welsh Borderland. New Phytol. 197:264-75.

Honegger, R., Axe, L. \& Edwards, D. 2013b. Bacterial epibionts and endolichenic actinobacteria and fungi in the Lower Devonian lichen. Chlorolichenomycites salopensis. Fungal Biology 117:512-8.

Hoshina, R. \& Imamura, N. 2009. Phylogenetically close group I introns with different positions among Paramecium bursaria photobionts imply a primitive stage of intron diversification. Mol. Biol. Evol. 26:1309-19.

Huelsenbeck, J. P. \& Ronquist, F. 2001. MrBayes: Bayesian inference of phylogeny. Bioinformatics 17:754-5.

Itten, B. \& Honegger, R. 2010. Population genetics in the homothallic lichen-forming ascomycete Xanthoria parietina. Lichenologist 42:751-61.

Johansen, S., Muscarella, D. E. \& Vogt, V. M. 1996. Insertion Elements in Ribosomal DNA Ribosomal RNA: Structure, evolution, processing, and function in biosynthesis. CRC Press, Boca Raton, FL, pp. 89-110.

John, D. M., Whitton, B. A. \& Brook, A. J. 2002. The Freshwater Algal Flora of the British Isles: An Identification Guide to Freshwater and Terrestrial Algae. Cambridge University Press, Cambridge, UK.

Kroken, S. \& Taylor, J. W. 2000. Phylogenetic species, reproductive mode, and specificity of the green alga Trebouxia forming lichens with the fungal genus Letharia. Bryologist 103:645-60.

Kuhsel, M. G., Strickland, R. \& Palmer, J. D. 1990. An ancient Group-I intron shared by eubacteria and chloroplasts. Science 250:1570-3.

Lindstrom, S. C. \& Pistolic, J. 2005. Detection of a Group I (IE) fungal intron in the green algal genus Urospora (Ulvophyceae). J. Phycol. 41:359-65. 
Maddison, W. P. \& Maddison, D. R. 2002. MacClade. Sinauer Associates, Sundarland, MA, USA.

McManus, H. A., Lewis, L. A., Fucikova, K. \& Haugen, P. 2012. Invasion of protein coding genes by green algal ribosomal group I introns. Mol. Phylogenet. Evol. 62:109-16.

Meier, F. A., Scherrer, S. \& Honegger, R. 2002. Faecal pellets of lichenivorous mites contain viable cells of the lichen-forming ascomycete Xanthoria parietina and its green algal photobiont, Trebouxia arboricola. Biol. J. Linnean Soc. 76:259-68.

Michel, F. \& Westhof, E. 1990. Modeling of the 3 dimensional architecture of group I catalytic introns based on comparative sequence analysis. J. Mol. Biol. 216:585-610.

Müller, K. M., Ellenor, D. W., Sherwood, A. R., Sheath, R. G., Cannone, J. J. \& Gutell, R. R. 2005. Evidence for lateral transfer of an IE intron between fungal and red algal small subunit rRNA genes. J. Phycol. 41:380-90.

Myllys, L., Kallersjo, M. \& Tehler, A. 1999. Variable sizes of introns in the SSU rDNA in three species of Roccella (Arthoniales, Euascomycetes). Curr. Genet. 36:79-85.

Nelsen, M. P. \& Gargas, A. 2008. Dissociation and horizontal transmission of codispersing lichen symbionts in the genus Lepraria (Lecanorales: Stereocaulaceae). New Phytol. 177:264-75.

Nelsen, M. P. \& Gargas, A. 2009. Symbiont flexibility in Thamnolia vermicularis (Pertusariales: Icmadophilaceae). Bryologist 112:404-17.

Nielsen, H. \& Johansen, S. D. 2009. Group I introns: moving in new directions. RNA Biol. 6:375-83.

Nishida, H. \& Sugiyama, J. 1995. A common group-I intron between a plant-parasitic fungus and its host. Mol. Biol. Evol. $12: 883-6$.

Nyati, S., Scherrer, S., Werth, S. \& Honegger, R. 2014. Green algal photobiont diversity (Trebouxia spp.) in representatives of Teloschistaceae (Lecanoromycetes, lichen-forming ascomycetes). The Lichenologist, in press. doi:10.1017/S0024282913000819.

Nylander, J. A. A. 2004. MrModeltest v2. Program distributed by the author. Evolutionary Biology Centre, Uppsala University. Available at: http://www.abc.se/ nylander/mrmodeltest2/ mrmodeltest2.html (last accessed May 15, 2013)

Piercey-Normore, M. D. \& DePriest, P. T. 2001. Algal switching among lichen symbioses. Am. J. Bot. 88:1490-8.

Pombert, J. F. \& Keeling, P. J. 2010. The mitochondrial genome of the entomoparasitic green alga Helicosporidium. PLoS ONE 5:e8954.

Pombert, J. F., Otis, C., Lemieux, C. \& Turmel, M. 2005. The chloroplast genome sequence of the green alga Pseudendoclonium akinetum (Ulvophyceae) reveals unusual structural features and new insights into the branching order of chlorophyte lineages. Mol. Biol. Evol. 22:1903-18.

Posada, D. \& Buckley, T. R. 2004. Model selection and model averaging in phylogenetics: advantages of Akaike Information Criterion and Bayesian approaches over likelihood ratio tests. Syst. Biol. 53:793-808.

Rambaut, A. 2008. FigTree version 1.3. Available at: http://tree. bio.ed.ac.uk/software/figtree/ (last accessed September 28, 2010).

Rambaut, A. \& Drummond, A. 2007. Tracer v 1.5. Available at: http://beast.bio.ed.ac.uk/Tracer (last accessed September $27,2010)$
Reeb, V., Haugen, P., Bhattacharya, D. \& Lutzoni, F. 2007. Evolution of Pleopsidium (lichenized ascomycota) S943 group I introns and the phylogeography of an intron-encoded putative homing endonuclease. J. Mol. Evol. 64:285-98.

Rindi, F. \& Guiry, M. D. 2003. Composition and distribution of subaerial algal assemblages in Galway City, western Ireland. Cryptogam. Algol. 24:245-67.

Ronquist, F. \& Huelsenbeck, J. P. 2003. MrBayes 3: Bayesian phylogenetic inference under mixed models. Bioinformatics 19:1572-4.

Ruoff, B., Johansen, S. \& Vogt, V. M. 1992. Characterization of the self-splicing products of a mobile intron from the nuclear rDNA of Physarum polycephalum. Nucleic Acids Res. 20:5899-906.

Sakamoto, Y., Ishiguro, M. \& Kitagawa, G. 1986. Akaike Information Criterion Statistics. D. Reidel, Dordrecht.

Sanchez-Puerta, M. V., Cho, Y., Mower, J. P., Alverson, A. J. \& Palmer, J. D. 2008. Frequent, phylogenetically local horizontal transfer of the cox1 group I Intron in flowering plant mitochondria. Mol. Biol. Evol. 25:1762-77.

Scherrer, S., De Vries, O., Dudler, R., Wessels, J. \& Honegger, R. 2000. Interfacial self-assembly of fungal hydrophobins of the lichen-forming ascomycetes Xanthoria parietina and X. ectaneoides. Fungal Genet. Biol. 30:81-93.

Simon, D., Moline, J., Helms, G., Friedl, T. \& Bhattacharya, D. 2005. Divergent histories of rDNA group I introns in the lichen family Physciaceae. J. Mol. Evol. 60:434-46.

Sogin, M., Ingold, A., Karlok, M., Nielsen, H. \& Engberg, J. 1986. Phylogenetic evidence for the acquisition of ribosomal RNA introns subsequent to the divergence of some of the major Tetrahymena groups. EMBO J. 5:3625-30.

Swofford, D. L. 2003. PAUP*. Phylogenetic Analysis Using Parsimony (*and Other Methods). Version 4. Sinauer Associates, Sundarland, MA, USA.

Tamura, K., Dudley, J., Nei, M. \& Kumar, S. 2007. MEGA4: molecular evolutionary genetics analysis (MEGA) software version 4.0. Mol. Biol. Evol. 24:1596-9.

Tavaré, S. 1986. Some probabilistic and statistical problems in the analysis of DNA sequences. Lectures on Mathematics in the Life Sciences (American Mathematical Society) 17:57-86.

Thompson, J. D., Gibson, T. J., Plewniak, F., Jeanmougin, F. \& Higgins, D. G. 1997. The CLUSTAL_X windows interface: flexible strategies for multiple sequence alignment aided by quality analysis tools. Nucleic Acids Res. 25:4876-82.

Turmel, M., Cote, V., Otis, C., Mercier, J. P., Gray, M. W., Lonergan, K. M. \& Lemieux, C. 1995. Evolutionary transfer of ORF containing Group-I introns between different subcellular compartments (chloroplast and mitochondrion). Mol. Biol. Evol. 12:533-45.

Vaughn, J. C., Mason, M. T., Sperwhitis, G. L., Kuhlman, P. \& Palmer, J. D. 1995. Fungal origin by horizontal transfer of a plant mitochondrial Group-I intron in the chimeric CoxI gene of Peperomia. J. Mol. Evol. 41:563-72.

Zuker, M. 2003. Mfold web server for nucleic acid folding and hybridization prediction. Nucleic Acids Res. 31:3406-15. 